\title{
STUDIES ON CHOLINE ACETYLASE (I)
}

\section{HIROSHI KUMAGAI, SETSURO EBASHI AND FUMIKO TAKEDA}

\author{
Department of Pharmacology, Faculty of Medicine, University of Tokyo, Tokyo
}

Received for publication April 26, 1954

The discovery of choline acetylase (1) has revealed the position of acetylcholine (ACh) in general metabolism. In view of the fact that certain drugs including narcotics and convulsants have some effects on ACh metabolism of brain, it is reasonable to suppose that some of these drugs might associate with the activity of choline acetylase.

In this paper, we have studied several problems regarding choline acetylase, especially the effects of certain drugs on this enzyme.

\section{METHOD}

The method was essentially the same as that of Nachmansohn (2), but in some respects we adopted new procedures, especially in the preparation of enzyme meterial.

(1) Enzyme source. Almost all the experiments were conducted by means of freeze-dried powder of rat or guinea pig brain. The freeze-dried powder weighed. 21-22\% of the original fresh tissues, while the acetone-dried powder 19-20\% thereof.

(2) Extraction and incubation. One hundred $\mathrm{mg}$. of dried tissue was ground to fine powder, to which $5 \mathrm{cc}$. of ice-cold solution A (see below) was added, mixed up and, after being left as it is for about 15 minutes at $5^{\circ} \mathrm{C}$, centrifuged at $1500 \times$ gravity for 15 minutes. To its separated supernatant solution B (see below) of equal volume was added, just before the incubation was carried out aerobically at $37^{\circ} \mathrm{C}$ for 20-150 minutes.

Solution A

$\begin{array}{ll}\mathrm{KCl} & 0.15 \mathrm{M} \\ \mathrm{NaCl} & 0.04 \\ \mathrm{MgCl}_{2} & 0.004 \\ \mathrm{NaF} & 0.01 \\ \mathrm{Na}_{2} \mathrm{HPO}_{4} & 0.032 \\ \mathrm{KH}_{2} \mathrm{PO}_{4} & 0.008 \\ \text { Eserine } & 0.003 \\ \text { Cysteine } & 0.006\end{array}$

Solution B

$\begin{array}{ll}\text { ATP } & 0.003-0.006 \mathrm{M} \\ \text { Choline } & 0.01 \\ \text { Citrate } & 0.02 \\ \text { Drugs } & \text { Iwice that of the } \\ & \text { required concentration }\end{array}$

pII was adjusted at 6.8

Preliminary report was presented at the 25th Annual Mee ings of the Japanese Pharmacological Society, on May, 1952 
RESUI,TS

\section{Preparation of Enzyme}

1) Comparative examination on various preparations of enzyme. In order to know the availability of the freeze-dried powder as an enzyme source of choline acetylase, it was compared with acetone dried powder and fresh tissue.

The result, as summarized in Table 1, showed that amount of ACh synthesized during the first 20 minutes' incubation with freeze-dried powder of rat brain as well as guinea pig brain surpassed at the significant level of 0.05 that with acetone dried powder.

TABLE 1. ACh synthesis by various enzyme materials

\begin{tabular}{|c|c|c|c|c|c|c|c|c|c|c|}
\hline \multirow{2}{*}{$\begin{array}{c}\text { Enzyme sources } \\
\text { Time }\end{array}$} & \multicolumn{3}{|c|}{ Acetone dried powder } & \multicolumn{3}{|c|}{ Freeze-dried powder } & \multicolumn{4}{|c|}{ Fresh tissues } \\
\hline & $20^{\mathrm{m}}$ & $I^{\text {h }}$ & $2.5^{\text {b }}$ & $20^{\mathrm{m}}$ & $1^{\mathrm{h}}$ & $2.5^{\mathrm{h}}$ & & $20^{\mathrm{m}}$ & $1 \mathrm{~h}$ & $2.5 \mathrm{~h}$ \\
\hline \multirow{2}{*}{ Rat brain } & $72(360)$ & $250(1250)$ & $500(2500)$ & $98(480)$ & $283(1330)$ & $390(1840)$ & \multirow[b]{2}{*}{$\mathrm{b}$} & \multirow{3}{*}{$\begin{array}{c}- \\
28 \\
47\end{array}$} & \multirow{3}{*}{$\begin{array}{l}46 \\
30 \\
81\end{array}$} & \multirow{2}{*}{$\begin{array}{l}48 \\
30\end{array}$} \\
\hline & $86(430)$ & $178(890)$ & $420(2100)$ & $95(445)$ & $168(790)$ & $358(1680)$ & & & & \\
\hline \multirow{2}{*}{ Guinea pig brain } & $63(315)$ & $118(590)$ & $210(1050)$ & $78(365)$ & $184(875)$ & $285(1350)$ & \multirow[t]{2}{*}{$c$} & & & \\
\hline & $68(340)$ & $120(600)$ & $272(1360)$ & $87(405)$ & $141(665)$ & $298(1415)$ & & & & \\
\hline
\end{tabular}

Figures refer to amount of $\mathrm{ACh}$ in $\mu \mathrm{g} . / \mathrm{g}$. fresh tissue ( $\mu \mathrm{g} . / \mathrm{g}$. powder shown in parenthesis). Acetone dried powder and freeze-dried one were prepared from the same animal.

(2) Effect of $\mathrm{pH}$ on ACh synthesis. As shown in Fig. 1, optimum pH for ACh synthesis with freeze-dried powder extracts of rat brain was about 7.4 in the earlier stage of incubation but in the later stage it shifted to acid side.

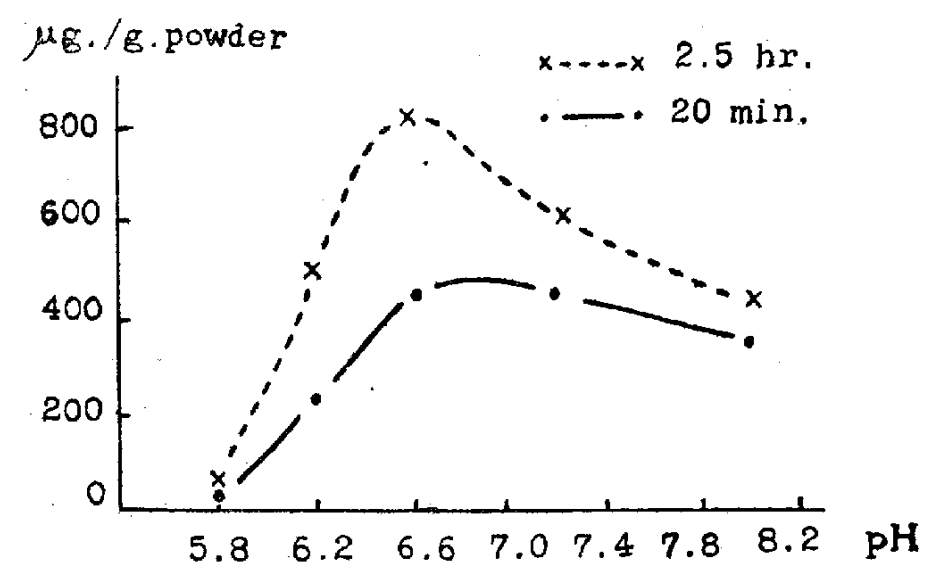

FIG. 1. Influence of $\mathrm{pH}$ on ACh synthesis.

Ordinate: Amount of ACh. Abscissa: $\mathrm{pH}$.

(3) Determination of $A C h$. The amount of synthesized ACh was determined biologically by esarinized M. rectus abdominis of Rana nigromaculate. After 20,60 and 150 minutes' incubation, a small part of incubated mixture was diluted at first 
with 30 volumes of $K$-free frog-Ringer solution and then with normal frog-Ringer solution until the suitable concentration of ACh for testing muscle, viz. 0.025-0.1 $\mu \mathrm{g}$. cc., was obtained. Then the response of muscle was observed by the use of this diluted solution. ATP, contained in the mixture, has a sensitizing effect on the response of muscle to $\mathrm{ACh}$, so that the values calculated from the response of muscle are always a little larger than the genuine ones. A correction therefor was made : the calculated amount of $\mathrm{ACh}$ in the mixture per cc. was decreased by $0.1 \mu \mathrm{g}$. or $0.05 \mu \mathrm{g}$. when the test was performed by 50 or 100 times the diluted solution. In case where more than 100 tinies diluted solution was used, correction was omitted.

The amount of $\mathrm{ACh}$ was expressed in terms of ACh-chloride equivalent.

\section{Distribution of Choline Acetylase in Central Nervous System}

Rat's or guinea pig's central nervous system was dissected into the following five parts.

A. Almost all parts of cerebral cortex, including the greater part of cerebral medulla and a small part of basal ganglia (the greater part of Ncl. amygdalae and a small caudal part of Claustrum, Putamen and Ncl. caudatus. The total amount of these parts corresponds to only one-tenth of the total basal ganglia).

B. Diencephalon, ammonhorn, the greater part of basal ganglia and a small part of cerebral cortex.

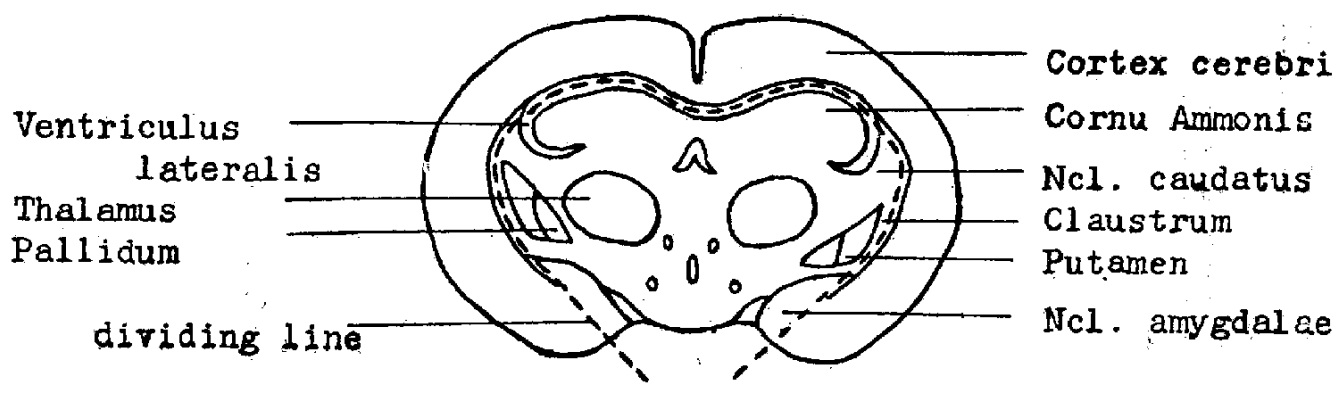

TABLE 2. ACh synthesis in central nervous system ( $\mu \mathrm{g} . / \mathrm{g}$. powder. hr.)

\begin{tabular}{c|c|c|c|c}
\hline Region Species & \multicolumn{2}{|c|}{ Rat } & Dog & Guinea pig \\
\hline A & 255 & 215 & 260 & 275 \\
\hline B & 545 & & 610 & 680 \\
\hline C & 785 & & 560 & 440 \\
\hline D & 50 & 65 & 45 & 115 \\
\hline F & 530 & 500 & 370 & 405 \\
\hline
\end{tabular}

As for $A, B, C, D$ and $E$, see the text,
C. Mesencephalon, medulla and pons.

D. Cerebellum.

E. Spinal cord.

$B$ was separated from A as indicated in Fig. 2, in order to leave basal ganglia in B. Fila olfactoria was omitted.

As for dog, A represents almost pure cortex.

As shown in Table 2, the amount of synthesized ACh was the largest 
in brain stem, less in spinal cord and cerebrum, and least in cerebellum.

\section{Effect of Drugs on Choline Acetylase}

A number of drugs, including convulsants and narcotics were studied with respect to their effect on $\mathrm{ACh}$ synthesis by chloline acetylase obtained from brain freeze-dried powder (Table 3). ACh determination by M. rectus abdominis of frog was so accurate as to detect even the difference of $3 \%$ between two samples. For each drug two controls were tested and when the standard deviation between the two controls was larger than $2 \%$, this experiment was given up. While in case of deviation less than $2 \%$, the mean value of the two was adopted as control. When the amount of synthesized ACh of sample with test drug was larger or smaller than the control by $5 \%$ more, the drug was regarded as a significant one.

'IABLE 3. Influence of drugs on ACh synthesis

A) Narcotics

\begin{tabular}{|c|c|c|c|c|c|}
\hline Drugs & Concentration & $1 \mathrm{mM}$ & $0.1 \mathrm{mM}$ & $0.01 \mathrm{mM}$ & Controls \\
\hline & Chloroform & $286(100)$ & $286(100)$ & $280(97)$ & $286 \triangle$ \\
\hline & Urethane & $520(98)$ & $520(98)$ & $580(100)$ & 580 \\
\hline & Barbitai-Na & $550(90)$ & $610(100)$ & $590(97)$ & 610 \\
\hline & Pentobarbital & $621(102)$ & $618(10 I)$ & $602(99)$ & 608 \\
\hline & Evipan-Na & - & $342(101)$ & $346(102)$ & $3 A 0 \triangle$ \\
\hline & Thiopentothal & $248(96)$ & $256(98)$ & $262(101)$ & $260 \wedge$ \\
\hline & Ëunarcon & $256(102)$ & $260(103)$ & $252(100)$ & $2 E 2 \triangle$ \\
\hline & Phenobarbital & $258(100)$ & $264(102)$ & $254(98)$ & $258 \wedge$ \\
\hline & Morphine & $202(97)$ & $314(101)$ & $314(701)$ & 310 \\
\hline & $\mathrm{KBr}$ & $495(98)$ & $520(104)$ & - & 504 \\
\hline
\end{tabular}

* Solitim of Lsopopyi-B-bromaliyi-N-methyl-malonyiurea

B) Convuisants

\begin{tabular}{|c|c|c|c|c|}
\hline Drugs & $1 \mathrm{~mm}$ & $0.1 \mathrm{mM}$ & $0.01 \mathrm{rM}$ & Controis \\
\hline Picrotoxin $\left\{\begin{array}{l}\overline{\text { normai mixiure }} \\
\text { NaCl } 0.12 \mathrm{M}, \mathrm{KCl} 0.02 \mathrm{M}\end{array}\right.$ & - & $\begin{array}{l}200(98)^{*} \\
205(104)^{*}\end{array}$ & $\begin{array}{l}205(100)^{* *} \\
190(99)^{* *}\end{array}$ & $\begin{array}{l}205 \wedge \\
195 \wedge\end{array}$ \\
\hline Scrychnine & $695(100)^{*}$ & $725(104)^{* *}$ & $705(101)^{* * *}$ & 605 \\
\hline CardiazoI & $57 x(101)$ & $570(101)$ & $565(100)$ & 565 \\
\hline Animocordine (Coramine) & $570(101)$ & $575(102)$ & $56 \Xi(100)$ & 565 \\
\hline Trans- $\pi$-Oxocampher (Vitacampher) & $488(91)$ & $480(99)$ & $480(105)$ & 483 \\
\hline Caffeine & $474(91)$ & $518(99)$ & $588(108)$ & 522 \\
\hline Phenol & $306(99)$ & $310(100)$ & $314(101)$ & $310 \wedge$ \\
\hline Benzedrine & $525(93)$ & $580(103)$ & $560(99)$ & 565 \\
\hline
\end{tabular}

$* 10 \mu \mathrm{g} / \mathrm{ml}, * 1 \mathrm{\mu g} / \mathrm{ml}, * * * 0.1 \mathrm{\mu g} / \mathrm{ml}$. 
C) Autonomic agents

\begin{tabular}{|c|c|c|c|c|c|}
\hline Drugs & Concentration & $1 \mathrm{~m} M$ & $0.1 \mathrm{mM}$ & $0.01 \mathrm{mM}$ & Controls \\
\hline & Adrenaline & $540(91)$ & $556(93)$ & $585(98)$ & 595 \\
\hline & Nor-Adrenaline & $513(90)$ & $570(99)$ & $570(99)$ & 573 \\
\hline & Dibenamine & $105(60)$ & $174(98)$ & $180(102)$ & $177 \triangle$ \\
\hline & Benzylimidazoline & $495(101)$ & $482(98)$ & $470(96)$ & 490 \\
\hline & Ergotamine & $250(103)^{*}$ & $240(99)^{* *}$ & $250(103)^{* * *}$ & $243 \wedge$ \\
\hline & Atropine & - & $250(102)$ & $240(98)$ & $245 \triangle$ \\
\hline & $\mathrm{C}_{\mathrm{n}}$ & $540(100)$ & $540(100)$ & $550(102)$ & 540 \\
\hline & TEAB & $505(103)$ & $485(99)$ & $482(98)$ & 490 \\
\hline
\end{tabular}

* $50 \mu \mathrm{g} / \mathrm{mI}, * * 5 \mu \mathrm{g} / \mathrm{ml}, * * * 0.5 \mu \mathrm{g} / \mathrm{ml}$.

D) Other drugs

\begin{tabular}{|c|c|c|c|c|c|}
\hline Drugs & Concentration & Inhibition & Drugs & Concentration & Inhïbition \\
\hline Histamine & & - & & $(1 \mathrm{mM}$ & + \\
\hline Benadryl & & - & & $\left\{\begin{array}{l}0.1 \\
0.01\end{array}\right\}$ & - \\
\hline Veratrin & $\left\{\begin{array}{c}100 \mu \mathrm{g} \\
10 \\
1\end{array}\right\}$ & - & $\begin{array}{l}\text { Vitamin } B_{2} \\
\text { Vitamin } B_{6}\end{array}$ & & $\begin{array}{l}- \\
-\end{array}$ \\
\hline Guanidine & & - & & $(1, \mathrm{mM}$ & + \\
\hline$d$-Tubocurarine & $\left\{\begin{array}{l}0.01 \mathrm{mM} \\
0.001\end{array}\right\}$ & - & Vitamin C & $\left\{\begin{array}{l}0.1 \\
0.01\end{array}\right\}$ & - \\
\hline $\mathrm{C}_{10}$ & $\left\{\begin{array}{l}0.1 \mathrm{mM} \\
0.01 \\
0.001\end{array}\right\}$ & - & $\begin{array}{l}\text { Vitamin } \mathrm{P} \\
\text { Vitamin } \mathrm{K}_{2}\end{array}$ & $\left\{\begin{array}{l}1 \mathrm{mM} \\
0.1\end{array}\right.$ & H+ \\
\hline Cocaine & & - & & $\langle 0.01$ & - \\
\hline Procaine & & - & Estrone $\left(\begin{array}{l}\text { Estradiol } \\
\text { Estrotriol }\end{array}\right)$ & & - \\
\hline $\begin{array}{l}\text { Digitoxin } \\
\text { Digoxin }\end{array}$ & & $\begin{array}{l}- \\
-\end{array}$ & Progesterone & & - \\
\hline$g$-Strophanthin & & - & Thyroxin & $\left\{\begin{array}{l}0.1 \mathrm{mM} \\
0.01 \\
0.001\end{array}\right\}$ & - \\
\hline $\begin{array}{l}\text { Quinine } \\
\text { Quinidine }\end{array}$ & $\left\{\begin{array}{l}0.1 \mathrm{mM} \\
0.01\end{array}\right\}$ & - & Insulin & $\left\{\begin{array}{l}44^{\text {unit }} \\
0.4^{0.04}\end{array}\right\}$ & - \\
\hline $\begin{array}{l}\text { Aconitin } \\
\text { Procaine-amide } \\
\text { Papaverine }\end{array}$ & & $\begin{array}{l}- \\
- \\
-\end{array}$ & Pituitrin & $\left\{\begin{array}{l}0.1 \text { unit } \\
0.01\end{array}\right\}$ & - \\
\hline
\end{tabular}

Figures indicate the amount of $\mathrm{ACh}(\mu \mathrm{g} . / \mathrm{g}$. powder. hr.); those in parenthese percentage of controls. Ratio of inhibition: + 5--10\%, H 10-20\%, H 20-30\%. Substrate (citrate) : $10 \mathrm{mM}(\triangle 2.5 \mathrm{mM})$.

\section{Effect of Metabolites}

Effects of some metabolites, especially those belonging to Krebs' cycle, on $\mathrm{ACh}$ synthesis by choline acetylase were observed. In this case we must consider some possibility that these metabolites themselves are also acetyl donors. We, therefore, observed the effects of these metabolites on the enzyme system without citrate, 
Result, as shown in Table 4, showed that ACh synthesis without citrate was accelerated moderately by acetate and slightly by glutamate.

TABLE 4. Influence of metabolites on ACh systhesis by choline acetylase

\begin{tabular}{l|c|c}
\hline & Citrate as substrate & Without substrate \\
\hline Control & 100 & 100 \\
Citrate & - & 375 \\
Acetate & 101 & 185 \\
Lactate & 90 & 88 \\
Malate & 89 & 90 \\
Fumarate & 86 & 90 \\
Succinate & 86 & 79 \\
x-Ketoglutarate & 13 & 24 \\
Pyruvate & 16 & 25 \\
Glutamate & 129 & $103(20 \mathrm{~m}: 113)$ \\
\hline Monofluoroacetate & 94 & 95 \\
Malonate & 102 & - \\
\hline
\end{tabular}

Figures are shown in parcentaga of control. Foubated for $60 \mathrm{~min}$.

\section{DISCUSSION}

\section{1) Preparation of enzyme material}

Indeed, acetone dried powder is a convenient source for choline acetylase. It is ready prepared and preserved; besides its cholinesterase content is very low (3). There is, however, no assurance that even a small part of $\mathrm{ACh}$ synthesizing system is not inactivated by acetone treatment. Accordingly we studied the relative yields of $\mathrm{ACh}$ by three enzyme sources; freeze-dried powder, fresh tissue and acetone dried powder. It was shown that the amount of synthesized ACh with acetone dried powder was less than that with freeze-dried powder, specifically in the earlier stage of incubation. In the later stage of incubation lasting for more than 60 minutes, acetone dried powder exceeded freeze-dried one in yielding $\mathrm{ACh}$. This tendency is not so remarkable in guinea pig brain. The reason for this superiority of acetone dried powder in longer incubation has not been yet adequately explained, but the inactivation of ATP-ase by acetone may account for it to a certain degree.

The amount of synthesized ACh with fresh tissue extracts is far less than the other two. Though the reason is not yet clarified, it may be partly due to adherence of the enzyme to cell structure.

2) $p H$

In longer period of incubation in weak alkaline solution, the rate of $\mathrm{ACh}$ synthesis was shown to go on decreasing: this may be du $z$ to the inactivation of the enzyme system or/and hydrolysis of ACh in alkaline medium. In experiments on choline acetylase, we should $\mathrm{b}$ a careful of $\mathrm{pH}$, particularly winen drugs to ba tested are added. 
3) Listribution of choline acetylase in central nervous system

There is a considerable difference in the amount of synthesized Ach according to the anatomical regions in the central nervous system. Table 5 shows the relative distribution of ACh, cholinesterase and choline acetylase in the central nervous system. The general trend of quantitative distribution of $\mathrm{ACh}$ seems to be in close parallel with that of choline acetylase, and is not so with that of cholinesterase. This suggests that the amont of $\mathrm{ACh}$ in brain may depend upon amount or activity of choline acetylase.

TABLE : Dis ribuition of ACh, cholinesterase and choline acetylase

\begin{tabular}{|c|c|c|c|c|c|}
\hline Resion & $\begin{array}{c}\mathrm{ACh} \\
(\mathrm{R}: \mathrm{t})^{(4)}\end{array}$ & Region & $\begin{array}{l}\text { Cholinesterase } \\
(\text { Dog })^{(5)}\end{array}$ & Region & $\begin{array}{c}\text { Choline acecyl } \\
\text { (Rat, Dog, } \\
\text { Guinea pig) }\end{array}$ \\
\hline Pallium & 100 & Cortex & 160 & A & 100 \\
\hline \multirow[t]{2}{*}{ Brain stem } & 150 & Diencephalon & 550 & $B$ & $200-250$ \\
\hline & & & & $\mathrm{C}$ & $200-250$ \\
\hline \multirow[t]{2}{*}{ Cerebellum } & 30 & Cerebellum & 1000 & $\mathrm{D}$ & $20-40$ \\
\hline & & Spinal cord & 150 & $\mathrm{E}$ & $150-200$ \\
\hline
\end{tabular}

Figures are shown in percentage of cortex or pallium.

4) Effects of drugs on choline acetylase

There are now good evidences that narcotics increase ACh content in brain, although the effect of convulsants is a complicated matter (6-8). As regards the effect of these drugs on enzymatic ACh synthesis, we find but a few papers. Recently McLennan and Elliot (9) published their studies on this problem by using brain slices. They revealed that both narcotics and convulsants presented an accelerating effect on ACh formation at low concentration and an inhibiting effect at high concentration.

In contrast with the above results, we demonstrated that both narcotics and convulsants have no effect on the ACh synthesis by choline acetylase. Thus, the enzymatic process differs from the metabolism of living tissue. Evidence already obtained indicates that narcotics have an inhibitory influence on respiration and ACh formation depends partially upon the latter. Therefore the effect of drugs on ACh formation in slices may be due to their effect on respiration, though the detailed mechanism is not yet made clear.

We can not agree with the preliminary report of McLennan and Elliot (9), announcing that narcotics and convulsants exerted an effect on enzymatic synthesis similar to that observed in slices.

We have found only a few of drugs which gave a remarkable effect on choline acetylase. The inhibiting action of dibenamine on choline acetylase may not relate with its pharmacological action. The inhibiting action of vitamin $\mathrm{K}$ has been reported by Nachmansohn (10).

5) Acetyl donor

There is no agreement whether the acetyl donor is acotate or citrate. While 
Nachmasohn (10) assumed only acetate to be a unique acetyl donor, other workers $(11,12)$ have been apt to admit citrate as a chief one. The present results showed that citrate was an excellent acetyl donor, while acetate was also utilized by guinea pig brain.

Among the usual metabolites, especially some members of Krebs' cycle, we could not find so remarkable accelerator as citrate and acetate. The inhibition caused by succinate, fumarate, lactate and malate was found to be so slight that it seems to have no physiological meaning.

The strongly inhibiting action of pyruvate and $\alpha$-ketoglutarate on $\mathrm{ACh}$ synthesis was already reported by Nachmansohn (3).

Both malonate and monofluoroacetate have no effect on $\mathrm{ACh}$ synthesis with citrate. This means that ACh synthesis from citrate does not pass through Krebs' cycle.

Glutamate, noticed by Nachmansohn (1) already at the time of discovery of this enzyme as an accelerator on $\mathrm{ACh}$ synthesis, is not yet clarified as to its role in ACh synthesis. According to this experiment, the matter remains to be studied.

\section{SUMMARY}

1. Narcotics and convulsants have no effect on acetylcholine synthesis by choline acetylase. Among the drugs tested hereby, dibenamine and vitamin $\mathrm{K}$ were proved to have some inhibiting effect on acetylcholine synthesis.

2. Acetylcholine synthesis by choline acetylase obtained from freeze-dried powder of guinea pig brain was remarkably accelerated by citrate, moderately by acetate and slightly by glutamate.

3. Distribution of choline acetylase in central nervous system of guinea pig, rat and dog, estimated from the amount of synthesized acetylcholine, was given in order of amount: brain stem $>$ spinal cord $>$ cerebrum $\gg$ cerebellum.

\section{REFERENCES}

1) NachmansohN, D., John, H.M. AND WAElsh, H.: J. biol. Chem. 150, 485 (1943)

2) NAchMANSOHN, D., HeSTrin, S. AND VorpaleFF, H.: Ibid. 180, 875 (1949)

3) NACHMANSOHN, D. AND JoHN, H.M.: Ibid. 158, 157 (1945)

4) NAKAJIMA, Y.: Jap.J. Surg. Soc. 52, I (1951)

5) GoTo, S.: Nisshin Igaku 37, 434 (1950)

6) Tobias, J.M., Lipton, M. A. and Lepinat, A. A.: Proc. Soc. Exper. Biol. \& Med. 61, 51 (1946)

7) Richter, D. And Crossland, J.: Am. J. Physiol. 159, 247 (1949)

8) Elliot, K. A. C., SwANK, R. C. AND HENDERSON, N. : Ibid. 162, 469 (1950)

9) Mclennan, H. ANd Elliot, K. A. C.: J. Pharmucol. \& Exper. Therat. 105, 35 (1951)

10) NACHMANSOHN, D. AND WEiss, M.S.: J. biol. Chem. 172, 677 (1948)

11) LIPTON, M. A. AND BARRON, E.S.G.: Ibid. 166, 358 (1946) 